\title{
USNRDL-TR-67-45
}

I3 April 9667

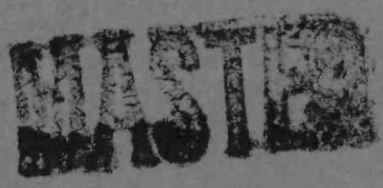

\section{PULSED REACTOR SIMULATION OF UNDERWATER NUCLEAR EXPLOSIONS}

\section{CFSTI PRICES}

by

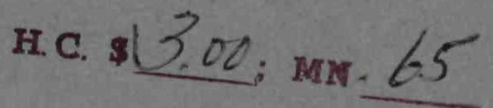

U.S. NAVAI RADIOLOGICAL

D E F E N S E L A BO RA TOR Y

SAN FRANCISCO. CALIFORNIA. 94135 
NUCLEAR APPLICATIONS BRANCH

D. L. Love, Head

NUCLEAR TECHNOLOGY DIVISION

R. Cole, Head

\section{ADMINISTRATIVE INFORMATION}

The work reported is part of a project sponsored by the Division of Biology and Medicine of the Atomic Energy Commission under Contract No. $\operatorname{AT}(49-7)-2886$

\section{ACKNOWLEDGMENT}

We would like to acknowledge the helpful assistance of $\mathrm{Mr}$. Robert Cordy and the KEWB reactor staff at Atomics International, Canoga Park, California, for help in carrying out the pulsed irradiation described.

\section{DDC AVAILABILITY NOTICE}

Each transmittal of this document outside the agencies of the U.S. Government must have prior approval of the Commanding Officer and Director, U.S. Naval Radiological Defense Laboratory, San Francisco, California 94135.

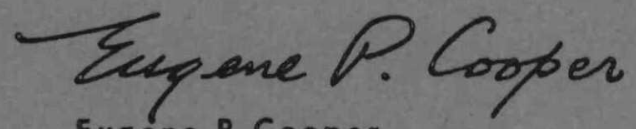




\section{DISCLAIMER}

This report was prepared as an account of work sponsored by an agency of the United States Government. Neither the United States Government nor any agency Thereof, nor any of their employees, makes any warranty, express or implied, or assumes any legal liability or responsibility for the accuracy, completeness, or usefulness of any information, apparatus, product, or process disclosed, or represents that its use would not infringe privately owned rights. Reference herein to any specific commercial product, process, or service by trade name, trademark, manufacturer, or otherwise does not necessarily constitute or imply its endorsement, recommendation, or favoring by the United States Government or any agency thereof. The views and opinions of authors expressed herein do not necessarily state or reflect those of the United States Government or any agency thereof. 


\section{DISCLAIMER}

Portions of this document may be illegible in electronic image products. Images are produced from the best available original document. 


\begin{abstract}
An underwater nuclear explosion was simulated by pulsing a $10 \mathrm{mg}$ foil of enriched U-235 with thermal neutrons from the IEWB reactor at Atomics Intemational. The purpose of the experiment was to produce the physical-chemical species of fission products as closely as possible to those produced in a real underwater nuclear explosion. Moving pictures and temperature measurements of the event showed that complete vaporization was not achieved, although melting did occur.
\end{abstract}

\title{
LEGAL NOTICE
}

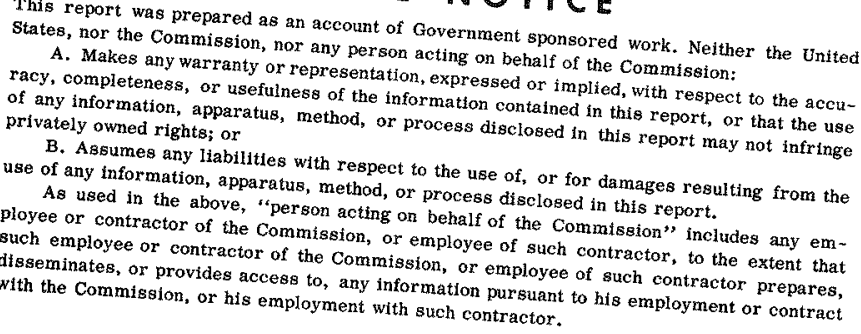




\section{SUMMARY}

A 10 mb foll of fully-enriched U-235 was placed in a capsule containing $5 \mathrm{ml}$ of seawater and pulsed with a period of $1.0 \mathrm{msec}$ by thermal neutrons from the KEWB Reactor at Atomics International. Calculations show that 4.1 calories of fission energy were needed to vaporize the uranium (its bolling point is $3900^{\circ} \mathrm{C}$ ). Determination of the number of fissions that took place from two different methods of determination indicated that between 3.1 and 7.1 calories were added (the 5.1 calories from the exothermic metal-water reaction did not occur). Temperatures in excess of $1300^{\circ} \mathrm{C}$ were obtained before the thermocouples failed. Moving pictures showed the uranium bead as iridescent and melting away (M.P. $1100^{\circ} \mathrm{C}$ ) from the thermocouple supports. It is believed that vaporization was almost achieved, but that it will take either an extra source of electrical energy to achieve it at KEWB or using another reactor such as a TRIGA Mark F (which would provide over three times the number of calories). Vaporization did not occur probably because only about the first half of the pulse (or half of the fission input energy) is used for vaporization - the heat losses in the second half of the pulse are too great to permit this half of the pulse to increase the temperature significantly. 
INTRODUCTION

The injection of radionuclides into the ocean by an underwater nuclear explosion creates a potential long-term hazard to man because of the possibility of the uptake of the radionuclide debris by marine organisms that are in man's food chain.

Prediction of the extent of the hazard is not possible because the extent of the uptake of radionuclides by marine organisms in the ocean is not known. That marine organisms do concentrate radionuclides has been well documented by analysis of maxine life exposed to radioactivity from weapons tests in the Pacific Ocean and laboratory studies of marine Iife in radioactively contaminated seawater.

One unknown factor in predicting the extent of the hazard is the lack of knowledge of the physical-chemical states of the radionuclide debris in the ocean. Radionuclide physical-chemical states are probably determined by their state at the time of addition to the ocean (or by the initial state and the decay of their precursors), and by the effects of the subsequent environment.

However, it is assumed in this work that in an underwater nuclear explosion the fate of the radionuclides if determined primarily by one or more parameters of the explosion process itself or of the environment immediately after the explosion. This report describes an experiment that simulates an underwater nuclear explosion in most of the parameters that would be important in characterizing the short-lived radionuclide debris. However it should be kept in mind that it is 
possible that the ultimate radionuclide species might be affected more by the history of the debris in the ocean environment than by the original explosion-produced state.

Briefly, the underwater nuclear explosion is simulated by placement of a small bead of uranium in a cell filled with seawater in the reflector region of a pulsed nuclear reactor. If the power output of the reactor is large enough, the temperature of the bead will reach several thousand ${ }^{\circ} K$ within a few milliseconds and the bead will vaporize. Careful calculations made by Schrock ${ }^{1}$ in an earlier program showed that temperatures in excess of the vaporization temperature of uranium can be reached by a $10 \mathrm{mg}$ bead of uranium metal. After the temperature of the mixture of fission products, induced activities and non-radioactive debris in the steam bubble cools below the individual vaporization temperatures and the nuclides condense or are adsorbed or occluded in material condensing at a higher temperature, they will pass through an environment similar to that produced by an underwater nuclear explosion in the ocean.

The purpose of this report is to show experimentally whether an uranium bead under such conditions as described above will be vaporized and to document the event as fully as possible.

Preliminary experiments ${ }^{*}$ have shown that pulsed uranium beads are vaporized in the E ring of the IRIGA reactor. This observation was arrived at by examination of the debris products that were formed. The pulsing of a bead of uranium in a vacuum results in a mirror deposit on the container walls. Pulsing the uranium bead in water results in a colloidal solution of uranium solids. It has been predicted by Schrock ${ }^{1}$ that under such pulsing conditions the temperature of the exploding uranium bead would reach, in a vacuum, 13,900 to $28,800{ }^{\circ} \mathrm{K}$ and in water $7000^{\circ} \mathrm{K}$.

* NRDL memorandum, L. Weisbecker to D. Love, 9 March 1965. 
In a pulsing reactor experiment, it would also be possible, in addition to observing the debris, to measure temperatures and pressures near the bead and to take moving pictures of the uranium metal bead during the pulsing event. It is these studies that are described in this report.

EXPERIMENTAL

The facility used was the Atomics International KEWB reactor (see Fig. 1). This site offered the use of both a sapphire-1ensed periscope leading to the surface of the reactor core reflector and a Fastax camera. The pulsed-neutron irradiation was utilized for these experiments by placing the capsule in the $8^{\prime \prime} \times 8^{\prime \prime}$ exposure facility which is in the graphite reflector and in close proximity to the core.

The capsule (Fig. 2) is shown in a view down through a. $1.5^{\text {"n }}$ sapphire window. The collinear lead-in wires for supporting the uranium-235 bead are two tungsten/tungsten rhenium thermocouples. The single wire is a chromel-alumel thermocouple for monitoring the capsule water temperature. The $10 \mathrm{mg}$ uranium strip is placed in the center gap between the collinear lead-in wires.

During the experiment the center hole behind the thermocouple gap is fitted with a piston attached to a linear motion transducer to give any transient volume changes during the experiment. The larger inlet contains a pressure transducer to follow capsule pressures.

All transient signals provided by the above measuring devices during the pulse were recorded on a high speed oscillogram monitored for timing by a precision $5 \mathrm{Kc}$ signal. After the experiment, records of the reactor power, water temperature, top fuel thermocouple temperature, bottom fuel thermocouple temperature, camera frames, stroboscope 


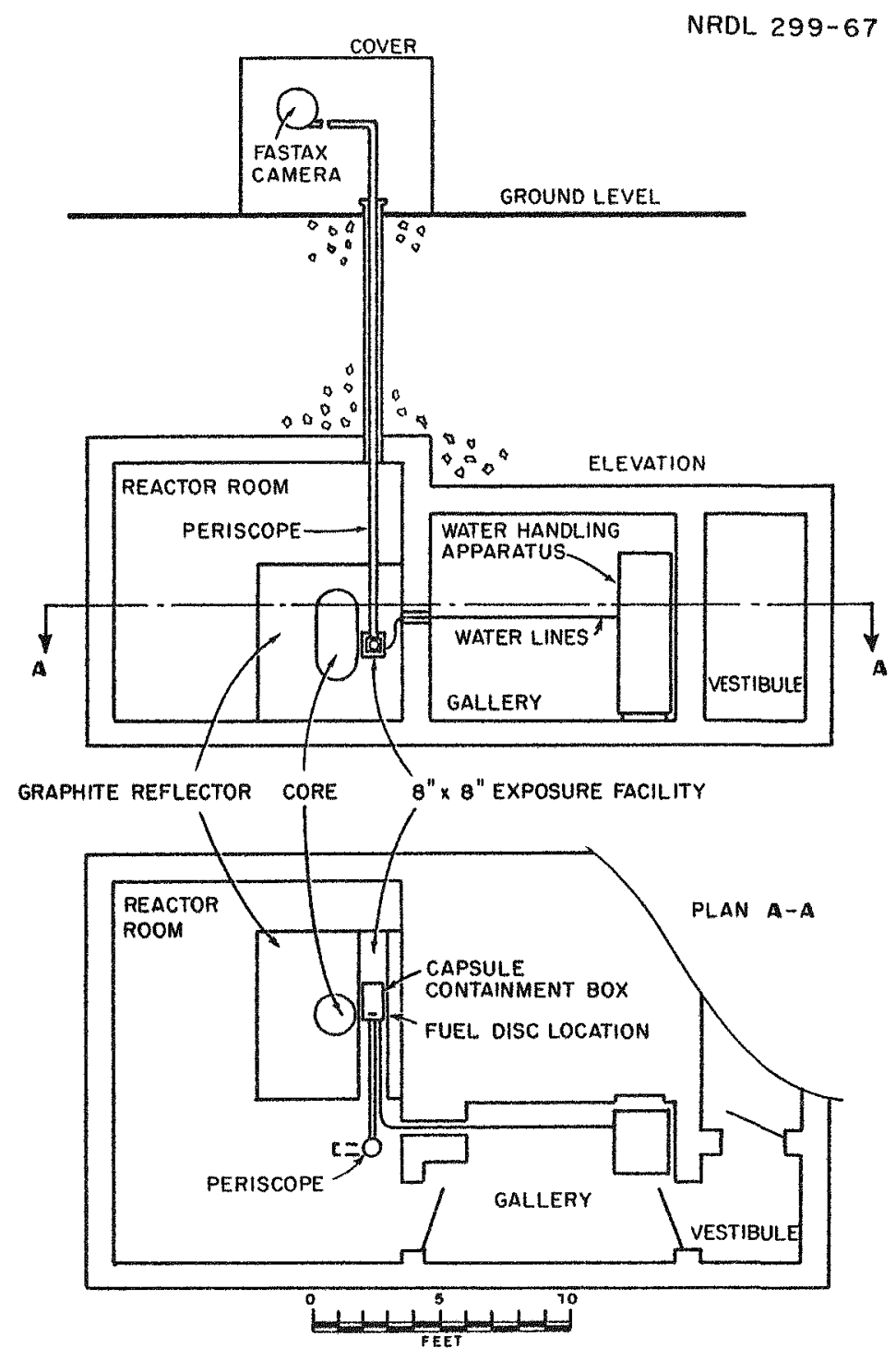

Fig. I Overall Arrangement of the Capsule Experiment at the KEWB Site. 


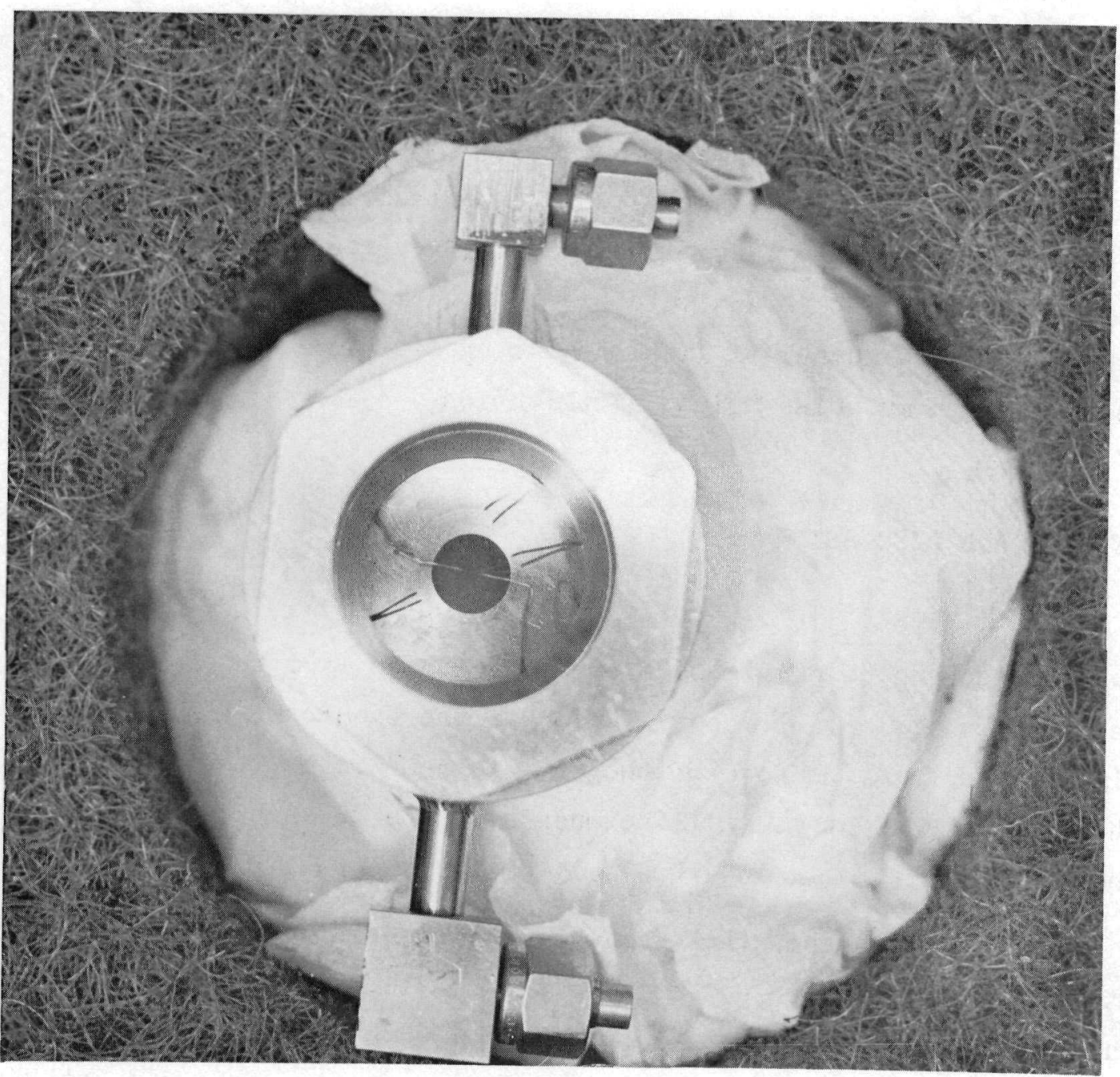

Fig. II The Irradiation Capsule (photograph supplied by Atomics International). 
firing, and capsule volume and pressure within 100 micro-second timing were available.

One method for the determination of the number of fissions was made by total decay gamma radiation in a high pressure ionization chamber. This ionization chamber had been precalibrated for numbers of fissions through radiochemical measurements. Experience has shown that the estimates obtained in this manner generally agreed to within $10 \%$ of radiochemically determined values. The other method used for the determination of the number of fissions was by measurement of gamma photopeaks in a gama pulse-height distribution.

RESULTS AND DISCUSSION

A sequence of prints of every other frame from the Fastax camera is show in Fig. 3. For correlation of the events of Fig. 3 with Fig. 4, a display of some of the oscillogram traces, the first picture should be placed at 6.4 milliseconds after pulse initiation. Each subsequent picture is in a 0.4 millisecond interval time sequence.

The pictures show the uranium reaching iridescence temperatures at about $7.6 \mathrm{~ms}$ (Frame 4), melting and starting to break away from the thermocouple leads at about $18 \mathrm{~ms}$ (Frame 30). Since the fuel did not vaporize, water temperature, volume and capsule pressure did not vary from ambient until much later in the time sequence.

From the plot of the fuel top thermocouple there is apparently a discontinuity at about $7.4 \mathrm{~ms}$ in the heating of the uranium. This discontinuity did not enter into the prediction of heat necessary to vaporize the fuel. Whatever phenomenon is occurring to cause this heat loss, it does represent a considerable heat sink. If the fuel had continued on the initial exponential heat rise it might have vaporized. 


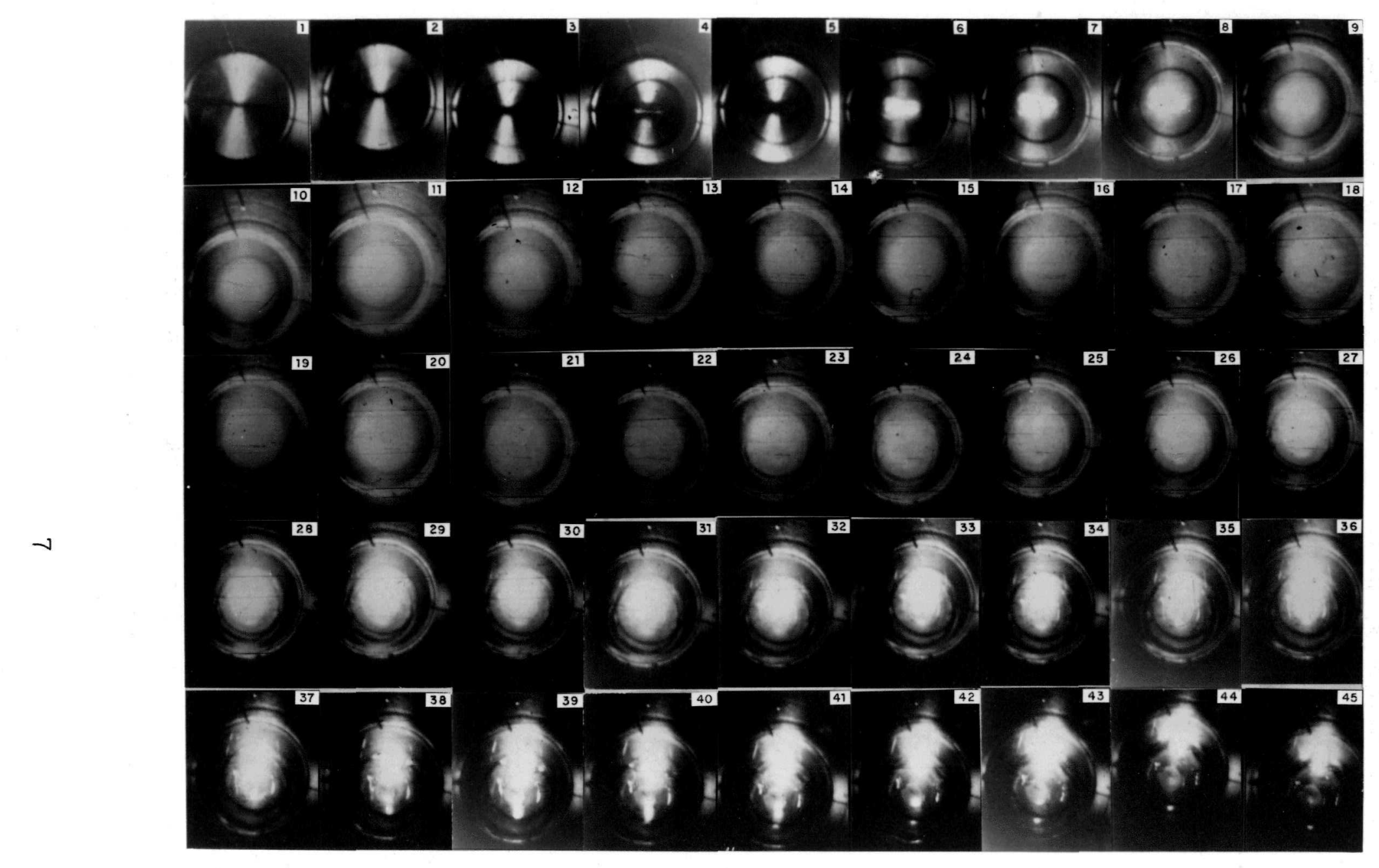

Fig. III Sequence of Pictures of the Neutron-Pulsed Uranium, From $6.4 \mathrm{~ms}$ to $24 \mathrm{~ms}$ After Pulse Initiation. The falling bead of uranium can be seen in the 45 th frame as a white dot about $1 / 6$ of the vertical distance up from the bottom of the picture. 
a

- 


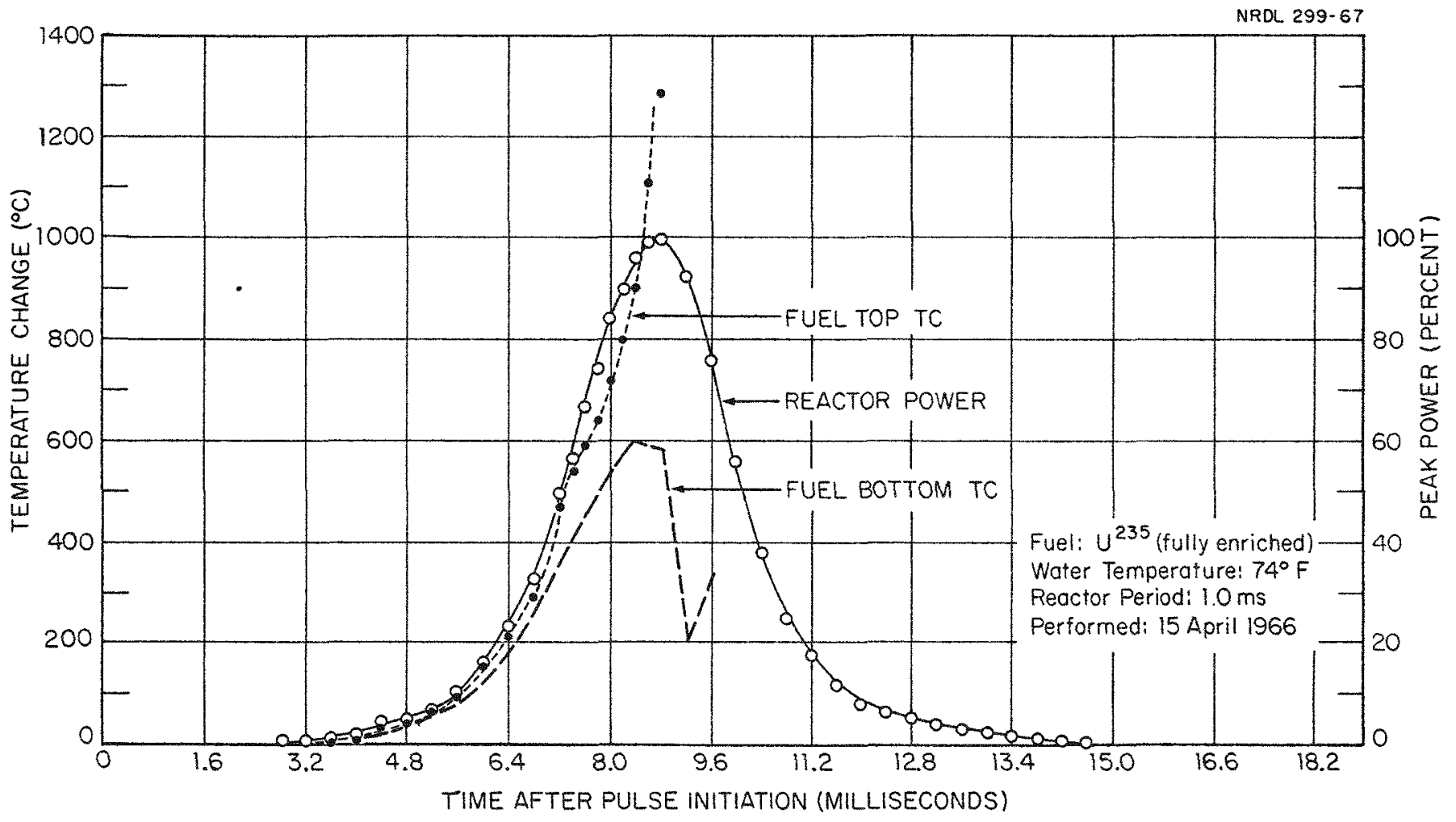

Fig. 4 Reactor Power and Temperature Profiles for Pulsed-Irradiation Experiment. 
The information used for the determination of the number of fissions in this experiment is given in Table $I$.

\section{Table I}

Calibration of the Number of Fissions in $10 \mathrm{mg}$ of U-235 in the KEWB Reactor

\begin{tabular}{|c|c|c|c|}
\hline \multirow[t]{2}{*}{ Reactor } & \multicolumn{2}{|c|}{ Fissions/10 mg } & \multirow{2}{*}{$\begin{array}{l}\text { Fission Energy }{ }^{* *} \text { Release/ } \\
10 \mathrm{mg} \text { of Unshielded U-235 } \\
\text { (Cal) }\end{array}$} \\
\hline & Shielded Fuel? & $\mathrm{U}-235$ & \\
\hline IRIGA， MARK F & $1.81 \times 10^{12}$ & $3.84 \times 10^{12^{*}}$ & 24.6 \\
\hline KШWB & $5.23 \times 10^{11}$ & $1.11 \times 10^{12}$ & 7.1 \\
\hline
\end{tabular}

* NRDL memorandum, L. Weisbecker to D. Love, 9 March 1965.

**A conversion factor of 6.4 cal per terafission was used. This was based on an energy of $167 \mathrm{Mev}$ per fission added to the uranium. $A$ value of 8 cal per terafission was used in the theoretical preditions used to calculate the maximum temperatures in Ref. 1.

The number of fissions for the $10 \mathrm{mg}$ of $\mathrm{U}^{235}$ in the KEWB reactor was determined by multiplying the reported KEWB value on the shielded fuel (gram amounts of uranium carbide) by the ratio of fissions in the shielded to the unshielded $10 \mathrm{mg}$ of $\mathrm{U}^{235}$ fuel run in the TRIGA reactor.

The radioactive solution resulting from the experiment was analyzed gamma spectrometrically for $\mathrm{Ce}^{141-144}, \mathrm{Zr}^{95}-\mathrm{Nb}^{95}, \mathrm{Cs}^{137}$, and $\mathrm{Ru}^{103-106}$. The $10.1 \mathrm{mg}$ bead of uranium was recovered after the experiment and found to weigh $9.1 \mathrm{mg}$. From the number of atoms of $\mathrm{Cs}^{137}$ in the solution containing $1.0 \mathrm{mg}$ of $U^{235}$, the number of fissions occurring in the $10.1 \mathrm{mg}$ bead of $\mathrm{U}^{235}$ was calculated to be $4.8 \times 10^{11}$ (equivalent to 3.1 cal). The other fission products analyzed gave a smaller number of fissions. These smaller values are probably due to their greater adsorption on the walls of the cell than that of the $\mathrm{Cs}^{137}$. The number 
of fissions calculated radiochemically is lower than the value shown In Table $I$ and is probably due to some adsorption of $\mathrm{Cs}^{137}$ onto the walls of the cell. This value for the number of fissions is considered a minimum value because the only way the value could be high would be from the leaching of $\mathrm{Cs}^{137}$ from the irradiated bead. This seems unlikely. On the other hand the value of $1.10 \times 10^{12}$ fissions given in Table I is probably a maximum value because of the thicker wall of the cell compared to those made in the calibration muns. It is felt that the true value for the number of fissions is about $1 \times 10^{12}$ (equivalent to 6.4 ca.1).

The amount of fission energy needed to vaporize the uranium can be estimated from the following considerations. Constant pressure heating consists of (1) heating the fuel to melting, (2) fusion, (3) heating the liquid fuel to vaporization, and (4) vaporization. Thus:

$$
Q=W\left[C_{p}\left(T_{m}-T_{o}\right)+Q_{p}+C_{p}\left(T_{b}-T_{m}\right)+Q_{v}\right]
$$

where

$$
\begin{aligned}
Q= & \text { heat required to vaporize uranium } \\
W= & \text { mass of uranium, here } 10 \mathrm{mg} \\
\mathrm{C}_{\mathrm{p}}= & \text { specific heat, at constant pressure, assumed equal for the } \\
& \text { solid and the } 1 \text { iquid } \\
\mathrm{T}_{\mathrm{m}}= & \text { melting point, } 1300^{\circ} \mathrm{C} \\
\mathrm{T}_{\mathrm{O}}= & \text { ambient temperature } \\
\mathrm{T}_{\mathrm{b}}= & \text { bolling point, } 3900^{\circ} \mathrm{C} \\
Q_{f}= & \text { heat of fusion } \\
Q_{\mathrm{v}}= & \text { heat of vaporization } \\
\text { therefore } & \\
Q= & 0.01 \mathrm{~g}\left[\left(0.04 \mathrm{cal} / \mathrm{g}-{ }^{\circ} \mathrm{C}\right)\left(1100^{\circ} \mathrm{C}\right)+11 \mathrm{cal} / \mathrm{g}+\left(0.04 \mathrm{cal} / \mathrm{g}-{ }^{\circ} \mathrm{C}\right)\right. \\
& \left.\left(2800^{\circ} \mathrm{C}\right)+243 \mathrm{cal} / \mathrm{g}\right] \\
Q= & 4.1 \mathrm{calories}
\end{aligned}
$$


It would appear, therefore, that the 6.4 cal available from fission would vaporize the bead. However, half of the fission energy is released during the falling exponential (or last half) of the reactor pulse. Heat losses due to radiation, conduction, and nucleate boiling during this phase are very large. Thus, most of the 3.2 cal developed during the falling half of the pulse is probably dissipated and therefore only about 3.2 cal are available to vaporize the bead.

The energy from the uranium metal-water reaction may be expected to contribute some heat to the reaction in addition to that from fission. A calculation of the exothermic uranium-water reaction gives 5.1 cal for a $10 \mathrm{mg}$ uranium sample:

$$
\begin{array}{ll}
\mathrm{U}+\mathrm{O}_{2} \rightarrow \mathrm{UO}_{2} & \frac{\Delta \mathrm{H}}{260,000} \\
2 \mathrm{H}_{2} \mathrm{O} \rightarrow 2 \mathrm{H}_{2}+\mathrm{O}_{2} & 140,000 \\
\hline \mathrm{U}+2 \mathrm{H}_{2} \mathrm{O}-2 \mathrm{H}_{2}+\mathrm{UO}_{2} & -120,000 \mathrm{cal} / \mathrm{mole}
\end{array}
$$

For 10 milligrams the gram atoms of $U-235=4.25 \cdot 10^{-5}$, so that the total chemical energy is

$$
Q_{\text {Chem }}=\left(4.25 \cdot 10^{-5}\right)(-120,000)=-5.1 \mathrm{cal}
$$

This should be a substantial contribution to the overall energy release in the capsule. Surprisingly, the chemical reaction did not go even though the metal reached at least $1300^{\circ} \mathrm{K}$ (see Fig. 4) before the thermocouple connection was broken.

For the complete vaporization to be visually demonstrated, it will either require an additional source of energy at KEWB, such as an electrical pulse giving about 2 calories to the sample, or a higher flux at another reactor. The first suggestion is cheaper and simpler although it could interfere with the simulation. The second will require setting up cameras and periscopes, which can be very expensive. 
REFFERENCES

1. V. E. Schrock, "Pulsed Reactor Simulation of Underwater Nuclear Detonations - Thermal Analysis," U.S. Naval Radiological Defense Laboratory, USNRDL-TR-940, 9 Apri1 1965.

2. L. W. Weisbecker, M. G. LaI, H. A. Goya, and H. I. Cordova, "Radionuclide Release From Aero-Space Nuclear Reactor Fuels.V. Phase Two: Pulsed Neutron Irradiation of Fuel in Water," U. $\mathrm{S}$. Naval Radiological Defense Laboratory, USNRDL-TR-1046, 24 May 1966. 
?

\section{,}

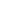


INITIAL DISTRIBUTION

\section{Copies}

NAVY

1

2

1

1

1

1

Chief of Naval Material (MAT PM 11)

Commander, Naval Ship Systems Command (SHIPS 2021)

Commander, Naval ship Systems Command (SHIPS 03541)

Commander, Naval Ship Systems Command (SHIPS 1622B)

Commander, Naval Ordnance Systems Command (ORD O3C)

Commander, Naval Facilities Engineering Command (FAC 042)

Chief of Naval Operations (Op-75)

Chief of Naval Operations (Op-09B5)

Director, Naval Research Laboratory (Code 2027)

Director, Naval Research Laboratory

CO, Office of Naval Research, Branch Office, San Francisco

$\mathrm{CO}$, Office of Naval Research, Branch Office, London

CO-Director, Naval Civil Engineering Laboratory

Supt., Naval Postgraduate School, Monterey

Chief of Naval Research (Code 419)

Commander, Naval Ordnance Laboratory, White Dak

CO-Director, Navy Electronics Laboratory

CO-Director, Navy Underwater Sound Laboratory

Commander, Naval Occanographic Office (Code 1640)

Co-Director, Naval Ship R\&D Center (Marine Engineering Laboratory)

Co, Naval Ordnance Test Station, Pasadena

Commander, Naval Ordnance Test Station, China Lake

Ocean Center (Small)

ARMY

Chicf of Research and Development (Atomic office)

$\mathrm{CG}$, Army Materiel Command (AMCRD-DE-NE)

Commandant, Chemical Center and School

Commander, Nuclear Defense Laboratory

CO, Army Engineer Research and Development Laboratory

USACDC Institute of Nuclear Studies

AIR FORCE

Director, USAF Project RAND 


\section{OTHER DOD ACTIVITIES}

Director, Defense Atomic Support Agency

Defense Documentation Center

\section{AEC ACTIVITIES AND OTHERS}

Argonne National Laboratory (Gustaf'son)

Atomic Energy Commission (Holland)

Coast Guard Oceanographic Center

Health and Safety Laboratory, AEC

Health and Safety Laboratory, AEC (Volchok)

Environmental Sciences Services Administration (Machta)

Johns Hopkins University (Pritchard)

Lamont Geological Observatory (Broecker)

Massachusetts Institute of Tcchnology, Dept. of Geo. and Geophy.

Massachusetts Institute of Technology (Corye11)

National Bureau of Standards (Library)

National Oceanographic Data Center (Director)

New York University (Dept. of Meterology and Oceanography)

Oregon State University Library (Osterberg)

Pacific Oceanography Group, Nanaimo, B.C.

Scripps Institute of Oceanography (Folsom, Craig)

Space Electric Power Office, AEC (Dix)

Texas A \& M University (Dept. of Oceanography and Meteorology)

University of Alaska (Geophysical Institute)

University of Hawaii (Cox)

University of Rhode Island, Narragansett Marine Laboratory

University of Washington, Applied Physies Laboratory

University of Washington, Dept. of Oceanography

Woods Hole Dceanographic Institute (Bowen)

Division of Technical Information Extension, Oak Ridge 


\section{USNRDL}

27 Technical Information Division

DISTRIBUTION DATE: 18 May 1967 
-

. 
Naval Radiological Defense Laboratory USNRDL-TR- $67-45$

PUTSED REACTOR SIMULATION OE UNDERWATER NUCLEAR EXPLOSIONS, by J. F. Pestaner and D. L. Love 13 April $196723 \mathrm{p}$. table illus.
2 refs.
UNCLASSIFIED 2 refs.

An underwater nuclear explosion was simleted by pulsing a $10 \mathrm{mg}$ foil of enriched $U-235$ with thermal neutrons from the KEWB reactor at Atomics International. The purpose of the experiment was to produce the physical-chemical species of fission products as closely as possio ble to those produced in a real underwater nuclear explosion. (over)

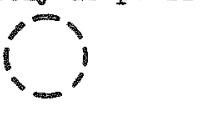

Underwater explosions - Simulation 2. Nuclear explosions 3. Fission products 4. Reactor materials

I. Pestaner, J.F. II. Love, D. L. III. Title
Naval Radiological Defense Laboratory USNRDL-TR-67-45

PUISED REACTOR STMLATION OF UNDERWATER NUCLEAR EXFLOSIONS, by J. F. Pestaner and D. L. Love 13 April $196723 \mathrm{p}$. table illus. 2 refs.
I. Underater explosions - Simulation 2. Nuclear explosions 3. Fission products

4. Reactor materials

An underwater nuclear explosion was sinulated by pulsing a $10 \mathrm{mg}$ foil of enriched U-235 with thermal neutrons from the KEWB reactor at Atomics International. The purpose of the experinent was to produce the physical-chemicel species of ission products as closely as possiunderwater nuclear explosion.

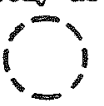

UICLASSIFIED
I. Pestaner, J. Fo II. Love, D. L.

III. Title ble to those produced in a real

underwater nuclear
(over)

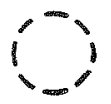

Moving pictures and temperature measurements of the event showed that complete vaporization was not achieved, although melting did occur.

\section{U.CLASS IFIED}

$-\frac{1}{2}$

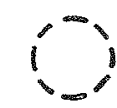

Moring pictures and temperature measurements of the event showed that complete vaporization was not achieved, although melting did occur. 
Naval Radiological Defense Laboratory

USNRDL-TR-67-45

PULSED REACTOR SIMULATION OF UNDERWATER NUCLEAR EXPLOSIONS, by J. F. Pestaner and D. L. Love 13 April 196723 p. table illus. UNCLASSIFIED

An undewater nuclear explosion was simulated by gulsing a $10 \mathrm{mg}$ foil of enriched U-235 with thermal neutrons from the KEWB reactor at Atomics International. The purpose of the experiment was to produce the physical-chemical species of fission products as closely as possible to those produced in a real underwater nuclear explosion.

(over)

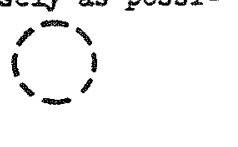

I. Pestaner, J. E. II. Love, D. I III. Title

U.TCLASS IFIED
Nava I Radiological Defense Iaboratory USNRDL-TR-67-45

PULSED REACTOR SIMULATION OF UNDEFWATER NUCLEAR EXPLOSIONS, by J. F. Pestaner and D. I. Love 13 April $196723 \mathrm{p}$. table illus. 2 refs. UNCLASSIFIED

An underwater nuclear explosion was simulated by pulsing a $10 \mathrm{mg}$ foil of enriched U-235 with thermal neutrons from the KEWB reactor at Atomics International. The purpose of the experiment was to produce the physical-chemical species of fission products as closely as possible to those produced in a real underwater nuclear explosion.

$$
\text { (over) }
$$

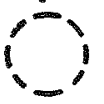

U.CLASSIFIED
1. Underwater explosions - Simulation

2. Tuclear explosions

3. Fission products

4. Reactor materials

Pestaner, J. F II. Love, D. L.

III. Titie

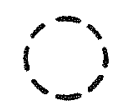

Moving pictures and temperature measurements of the event showed that complete vaporization was not achieved, although melting did occur.

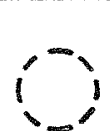

Moving pictures and texperature measurements of the event showed that complete vaporization was not achieved, although melting did occur. 
Naval Radiological Defense Laboratory USNRDL-TR-67-45

PULSED REACTOR SIMULATION OF UNDERWATER NUCLEAR EXPLOSIONS, by J. F. Pestaner and D. L. Love 13 April $196723 \mathrm{p}$. table illus.
2 refs. 2 refs.

An underwater nuclear explosion was simulated by pulsing a $10 \mathrm{mg}$ foil of enriched U-235 with thermal neutrons from the KNWB reactor at Atouics International. The purpose of the experiment was to produce the physical-chemical species of fission products as closely as possible to those produced in a reel underwater nuclear explosion. (over)

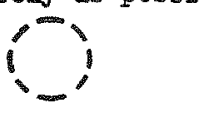

1. Underwater explosions - Simulation 2. Muclear explosions 3. Fission products 4. Reactor materials

I. Pestaner, J. $\vec{F}$. II. Love, D. L. III. Title
Naval Radiological Defense Laboratory USRRDL-TR-67-45

FTLSFD REACTOR STMULATTON OF UNDERAATEP NUCLEAR EXPLOSIONS, by J. F. Pestaner and D. L. Love 13 April 196723 pe table illus. 2 refs. UNCLASSIFIED

An underwater nuclear explosion was simulated by pulsing a $10 \mathrm{mg}$ foil of enriched U-235 with thermal neutrons from the KEWB reactor at Atomics International. The purpose of the experiment was to produce the physical-chemical species of fission products as closely as possile to those produced in a real underwater nuclear explosion. (over)

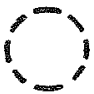

U.CLASSIFIED

1

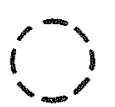

Moving pictures and temperature measurements of the event showed that complete vaporization was not achieved, although melting did occur. 
Naval Radiological Defense Laboratory

USNRDL-TR-67-45

PULSED REACTOR SIMULATION OF UNDEKWATER NUCLEAR EXPLOSIONS, bY J. F. Pestaner and D. L. Love 13 April 196723 p. table illus.

$$
13 \text { April } 196723 \text { p. table illus. }
$$

An underwater nuclear explosion was simulated by pulsing a $10 \mathrm{mg}$ foil of enriched U-235 with thermal neutrons from the KEWB reactor

at Atomics Intemational. The purpose of the

experiment was to produce the physical-chemical

species of fission products as closely as possi-

ble to those produced in a real

underwater nuclear explosion.

(over)

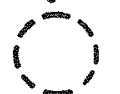

UICEASSIFIED II. Love, D. L III. Title

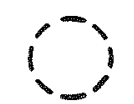

Moving pictures and temperature measurements of the event showed that complete vaporization was not achieved, although melting did occur.
Naval Radiological Defense Laboratory

USNRDL $-T R-67-45$

PUISED REACTOR SDUIATION OF UNDERNATER NUCLEAR EXPLOSIONS, by J. F. Pestaner and D. L. Love 13 April 196723 p. table illus. 2 refs.

UNCLASSIFIED

An underwater nuclear explosion was simulated by pulsing a $10 \mathrm{mg}$ foil of enriched U-235 with thermal neutrons from the KEWB reactor at Atomics International. The purpose of the experiment was to produce the physical-chemical species of fission products as closely as possible to those produced in a real underwater nuclear explosion.

$$
\text { (over) }
$$

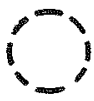

I. Pestaner, J.F. II. Love, D. L. III. Title

\section{UICLASSIFIED}

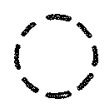

Moving pictures and temperature measurements of the event showed that complete vaporization was not achieved, although melting did occur. 